\title{
Snake venom causes apoptosis by increasing the reactive oxygen species in colorectal and breast cancer cell lines
}

This article was published in the following Dove Press journal:

OncoTargets and Therapy

20 October 2016

Number of times this article has been viewed

\author{
Abdulrahman Khazim \\ Al-Asmari' \\ Anvarbatcha Riyasdeen' \\ Mohammad Hamed \\ Al-Shahrani² \\ Mozaffarul Islam' \\ 'Research Center, ${ }^{2}$ Pediatric \\ Hematology/Oncology and Bone \\ Marrow Transplant Unit, Prince Sultan \\ Military Medical City, Riyadh, Kingdom \\ of Saudi Arabia
}

Correspondence: Abdulrahman Khazim Al-Asmari

Research Center, Prince Sultan Military Medical City, PO Box 7897 (777-S),

Riyadh II I59, Kingdom of Saudi Arabia

Tel +966 | $47777 \mid 4 \times 25100$

Fax +966 | 478660 ।

Email abdulrahman.alasmari@gmail.com
Abstract: Snake venom possesses various kinds of proteins and neurotoxic polypeptides, which can negatively interfere with the neurotransmitter signaling cascade. This phenomenon occurs mainly due to the blocking of ion channels in the body system. Envenomation prevents or severely interrupts nerve impulses from being transmitted, inhibition of adenosine triphosphate synthesis, and proper functioning of the cardiac muscles. However, some beneficial properties of venoms have also been reported. The aim of this study was to examine the snake venom as an anticancer agent due to its inhibitory effects on cancer progression such as cell motility, cell invasion, and colony formation. In this study, the effect of venoms on phenotypic changes and the change on molecular level in colorectal and breast cancer cell lines were examined. A reduction of $60 \%-90 \%$ in cell motility, colony formation, and cell invasion was observed when these cell lines were treated with different concentrations of snake venom. In addition, the increase in oxidative stress that results in an increase in the number of apoptotic cancer cells was significantly higher in the venom-treated cell lines. Further analysis showed that there was a decrease in the expression of pro-inflammatory cytokines and signaling proteins, strongly suggesting a promising role for snake venom against breast and colorectal cancer cell progression. In conclusion, the snake venoms used in this study showed significant anticancer properties against colorectal and breast cancer cell lines.

Keywords: colorectal cancer, breast cancer, cell motility, colony formation, oxidative stress, apoptosis, IL-8, IL-6, RhoC, p-Erk ${ }^{1 / 2}$

\section{Introduction}

Snake envenomation is a common phenomenon worldwide in general and in the Kingdom of Saudi Arabia in particular. It has been estimated that $\sim 421,000$ snake bites occur annually worldwide, out of which $\sim 50 \%$ of victims do not survive. ${ }^{1}$ In the Kingdom of Saudi Arabia, 51 species of terrestrial snakes have been reported, out of which nine species are considered to be highly poisonous. Mostly, these snakes belong to the following families: Hydrophiinae, Elapidae, Viperidae, and Atractaspididae. The few prominent and local species of snakes that are poisonous include Walterinnesia aegyptia, Atractaspis microlepidota, Cerastes gasperettii, and Echis coloratus. ${ }^{2}$ Clinical manifestation mainly depends on the type of the species of snakes.

Chemically, snake venom is a complex mixture of several enzymes and toxic proteins. Phospholipases A2 is one of the predominant components found in the snake venoms. The abundance of this enzyme is responsible for neuro- and cytotoxicities, edema, thrombocytopenia, and impairment of blood clotting factors. ${ }^{3}$ In addition, researchers have discovered the presence of L-amino acid oxidase and disintegrin 
in snake venoms that can damage cellular integrity. ${ }^{4}$ Interestingly, under proper pharmacological regulation, snake venoms can be beneficial in treating certain types of chronic diseases including cancer.

In addition, Marsh and Williams ${ }^{5}$ reported that snake venoms have cytotoxic effects on cancer cells. Several reports have also suggested the cytotoxic effect of snake venoms against various types of cancers. ${ }^{6-8}$ Treatment with venoms not only produces toxic effect on the cells but also interferes with the transport of nourishing substances needed for the growth of tumors. This phenomenon leads to the inhibition of signal transduction cascade mechanisms. ${ }^{9}$ In this study, we observed an interesting outcome as a result of treating colorectal and breast cancer cell lines with snake venom; RhoC, a pro-metastatic oncoprotein, was downregulated in snake-venom-treated MDA-MB-231 cell line, which results in the downregulation of interleukin (IL)-6. Our findings are in agreement with the previously published work, where RhoC knockdown was shown to inhibit the expression of IL-6 as well as decrease the phosphorylation of STAT3, thereby resulting in the downregulation of the expression of embryonic stem cell transcription factor "nanog". ${ }^{10,11}$

In this study, venoms from four different species of snakes, namely 1) Bitis arietans, 2) C. gasperettii, 3) E. coloratus, and 4) Echis pyramidum, were used. One of the objectives of the study was to evaluate the anticancer properties of the aforementioned species of the snakes. As reported earlier, snake venom did not show any effect on normal cancer cells (CCD180co). ${ }^{12}$ In the light of this published work and also due to the lack of the availability of primary cells to the investigators, we assumed the selective nature of snake venoms toward cancerous cells only.

The rationale of the study is to establish the molecular mechanism by which snake venoms work against colorectal and breast cancer progression. Our study shows the toxic effect of venoms, which increases the concentration of reactive oxygen species (ROS), resulting in the enhancement of apoptosis in cancer cells. To the best of the authors' knowledge, no one as yet has provided studies in detail that show the molecular aspect as well as anticancer properties of these snake venoms found in the Kingdom of Saudi Arabia.

\section{Materials and methods Snakes and venom collection}

The collection of snakes and their venom isolation were performed after the approval was granted by the Research Ethics Committee (REC) of Prince Sultan Military Medical City (PSMMC) hospital. The same committee (REC) is also responsible for animal care unit at PSMMC. Further, the study was conducted at the Research Center of PSMMC hospital. All animal experiments were performed based on the guideline set-forth for the use of animals by the Research Ethics Committee, PSMMC, Riyadh, Kingdom of Saudi Arabia. Medically important snakes were captured live from different regions of the Kingdom of Saudi Arabia. These species do not fall under the categories of endangered species and are abundantly found in this area. ${ }^{13}$ The snakes were fed with live mice and water ad libitum. The painless milking of the snake venom was performed by trained staff with proper safety precautions. ${ }^{14}$ The ejected venom was collected in a glass beaker, lyophilized, and stored at $-80^{\circ} \mathrm{C}$ until required. Stock venom concentration of $10 \mathrm{mg} / \mathrm{mL}$ in phosphate-buffered saline (PBS) was prepared and sterilized by passing through a $0.22 \mu \mathrm{m}$ membrane filter prior to its use. Further dilution, as per the experimental needs, was performed in the same buffer system. For simplicity, we designated the venoms as V1, V2, V3, and V4, which were obtained from the following species of snakes: 1) B. arietans, 2) C. gasperettii, 3) E. coloratus, and 4) E. pyramidum, respectively.

\section{Cell culture}

Cancer cell lines, namely HCT-8 (derived from the ileocecal adenocarcinoma of a 67-year-old male) ${ }^{15}$ and MDA-MB-231 (obtained from cancerous breast mammary glands), ${ }^{16}$ were kindly supplied by the cancer research facilities, King Saud Bin Abdulaziz Medical City Hospital, Ministry of National Guard-Health Affairs, Riyadh, Kingdom of Saudi Arabia. These cell lines were cultured according to the standard procedure as described earlier. ${ }^{17}$

\section{Clonogenic survival assay}

The clonogenic survival assay was performed according to Datta et al. ${ }^{18}$ Briefly, 500 cells were allowed to grow in sixwell plates for 2 weeks in the absence or presence of different concentrations of venoms as mentioned earlier. The cell culture media were replenished every third day with fresh venom added therein. At the termination of the assay, cells were rinsed with PBS. Colonies thus formed were stained for 45 minutes with $0.5 \%(\mathrm{w} / \mathrm{v})$ crystal violet prepared in $0.6 \%(\mathrm{v} / \mathrm{v})$ glutaraldehyde solution, rinsed with water, and finally air-dried.

\section{Cell motility assay}

Cell motility assays were carried out in a six-well cell culture plate as described by Islam et al. ${ }^{19}$ Briefly, cells were supplemented with complete medium and allowed to grow in the absence or presence of different concentrations of 
snake venoms (V1-V4) as obtained from the four different species of snakes as described earlier. The migration of cells from the edge of the groove toward the center was monitored microscopically at $200 \times$ magnifications 24 hours after treatment with different concentrations of snake venoms to assess the extent of scratched area covered. Percent motility was calculated as described earlier by one of the coauthors (MI) of this article..$^{20}$ Briefly, the width of the scratch was measured at 0 hour (before treatment) and after 24 hours (after treatment) to calculate the percentage of the gap covered by the cells in this time period.

\section{Cell invasion assay}

Cell invasion assays were performed using BD Bio-Coat Matrigel Invasion Chamber, which was obtained from BD Biosciences (Bedford, MA USA). The procedure was followed according to the manufacturer's instructions and also as described earlier. ${ }^{20}$

\section{Determination of ROS}

To evaluate the effect of snake venoms on ROS generation, the assay was conducted on the Muse Cell Analyzer (Millipore, Bedford, MA, USA) using the ROS Kit (Cat no MCH 100111-2; Millipore). Staining procedure was followed as per the manufacturer's protocol.

\section{Apoptosis assay}

To evaluate the extent of apoptosis caused by snake venoms, the assay was performed on the Muse Cell Analyzer using Annexin V and Dead Cell Kit (Cat No MCH 100105; Millipore). Total apoptosis was calculated by summing up the number of cells from late and early apoptotic quadrants of the histograms.

\section{Enzyme-linked immunosorbent assay (ELISA)}

The assay for the expression of IL- 8 and IL- 6 in snakevenom-treated samples was performed as described by Duffy et al. ${ }^{21}$ Briefly, the complete Dulbecco's Modified Eagle's Medium (DMEM) containing 10\% fetal bovine serum was replaced by DMEM containing $1 \%$ bovine serum albumin (BSA; to avoid interference of high concentration of serum in the assay), and cells were incubated in this condition for 6 hours. Next, cells were exposed to snake venoms and further incubated for 24 hours. At the completion of the incubation, cell culture media were collected, centrifuged at $1,000 \mathrm{rpm}$ for 5 minutes to remove the cell debris, and stored at $-80^{\circ} \mathrm{C}$ until used. The attached cells were trypsinized and counted for normalizing the concentration of cytokines.
The assay was performed on pre-coated human IL-8 and IL-6 ELISA plates procured from R\&D Systems (Minneapolis, MN, USA). Experiments were performed as per the manufacturer's guideline. Color intensity was read on the Hidex Sense Microplate Reader (Hidex, Turku, Finland) at $450 \mathrm{~nm}$. The expression was normalized by the number of cells in each group and depicted in the form of bar graphs. The concentrations of cytokines were reported in terms of picogram per milliliter per million of cells.

\section{Western blot analysis}

The experiments were performed on the W3 Western Workflow Complete System (Bio-Rad Laboratories Inc., Hercules, CA, USA). Equal amounts of proteins isolated from the MDA-MB-231 cell line (control and snake-venomtreated cell lysates) were mixed with $4 \times$ Laemmli buffer. ${ }^{22}$ The samples were boiled at $97^{\circ} \mathrm{C}$ for 5 minutes and then separated on $4 \%-12 \%$ sodium dodecyl sulfate gels. Proteins were transferred onto the pretreated polyvinylidene difluoride membranes. After blocking the membranes in 3\% BSA for 1 hour, they were probed with 1:1,000 diluted rabbit polyclonal $\operatorname{Erk}^{1 / 2}$ (pT202/pY204) + (pT185/pY187) and RhoC antibodies (Abcam, Cambridge, UK). GAPDH (1:2,500 dilutions) was used as a loading control. After overnight incubation at $4{ }^{\circ} \mathrm{C}$, membranes were washed and blotted for 1 hour with horse radish peroxidase-conjugated anti-rabbit secondary antibodies $(1: 2,500)$. Next, bands were visualized in ChemiDoc MP imaging system using enhanced chemiluminescence detection reagents; band density was calculated using Image Lab 5.0 (Bio-Rad Laboratories Inc.), and the normalized values were depicted in the form of bar graphs.

\section{Statistical analysis}

Statistical analyses were performed using Student's $t$-test. The mean was reported with \pm standard deviation. Differences were considered to be statistically significant when $P$-values were $\leq 0.05$.

\section{Results \\ Functional analysis of snake venoms on HCT-8 and MDA-MB-23 I cell lines}

To assess the effectiveness of snake venoms, we performed the anchorage-dependent colony formation assay in HCT-8 and MDA-MB-231 cell lines in the absence or presence of snake venoms. Furthermore, cell motility, which is an immensely important parameter in cancer survival and progression, was also assayed under the same treatment conditions. In this study, we observed a distinguishable decrease in colony formation in HCT-8 and MDA-MB-231 cell lines when treated 
with two different concentrations of snake venoms $(5 \mu \mathrm{g} / \mathrm{mL}$ and $10 \mu \mathrm{g} / \mathrm{mL}$ ). Our pilot studies showed that cells having concentations $<5 \mu \mathrm{g} / \mathrm{mL}$ were unresponsive and $>10 \mu \mathrm{g} / \mathrm{mL}$ were morphologically distorted completely; hence, these two concentrations were selected for the treatment of the cell lines. The corresponding bar graph shows the quantitative analysis of the colonies formed (Figure 1A-D). As shown in Figure $1 \mathrm{~A}-\mathrm{D}, \sim 85 \%-95 \%$ reduction in colony formation was observed after treatment with the venoms. In addition, we observed a perceptible decrease in cell motility when these cell lines were challenged with snake venoms. Bar graphs represent the extent of decrease in cell motility upon venom treatment (Figure 2A and B). A significant decrease in the cell motility was observed when the cell lines were treated with two different concentrations of venoms. A decrease of $60 \%-90 \%$ in cell motility was noticeable in HCT-8 and MDA-MB-231 cell lines when compared with their corresponding controls. In addition, a dramatic decrease (50\%-90\%) in Matrigel invasion was observed upon venom treatments (Figure 3A-D).

\section{Snake venoms generate ROS in HCT-8 and MDA-MB-23I cell lines}

To elucidate the probable cause of phenotypic changes in these cell lines after treating them with snake venoms, we determined the generation of ROS on the Muse Cell Analyzer using the Muse Oxidative Stress Kit (Cat no MCH 100111-2) from Millipore. As shown in Figure 4A and B, a significant increase in ROS was observed in venom-treated cell lines. However, at the lower concentration of V1 $(5 \mu \mathrm{g} / \mathrm{mL})$, colorectal cancer did not show significant ROS production. Similarly, V1 and V2 at the same concentration $(5 \mu \mathrm{g} / \mathrm{mL})$ also did not achieve the significant levels of ROS production in breast cancer cell line. This phenomenon could be due to the differential uptake of the venoms in this particular setup of the experiments. Furthermore, it is a well-established phenomenon that ROS is also responsible for the induction of apoptosis in cancer cells. ${ }^{23,24}$ Therefore, our next aim was to examine the extent of apoptosis in venom-treated cell lines. In our future study, a detailed description of mitochondrial
A

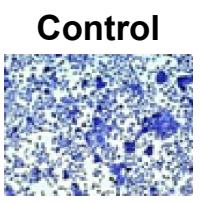

\section{V1}

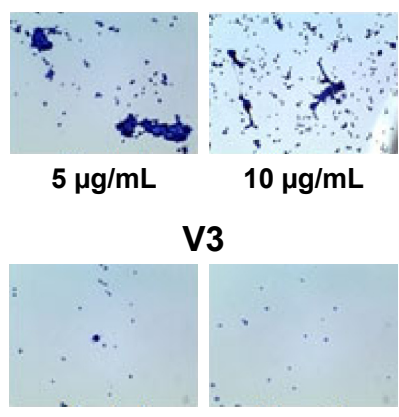

$5 \mu \mathrm{g} / \mathrm{mL}$

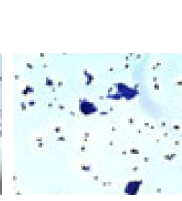

$5 \mu \mathrm{g} / \mathrm{mL}$

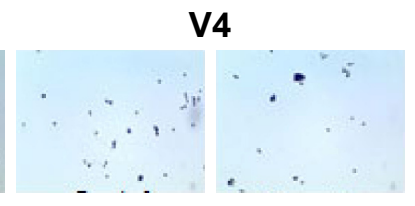

$5 \mu \mathrm{g} / \mathrm{mL}$
V2

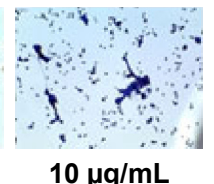

V4

C

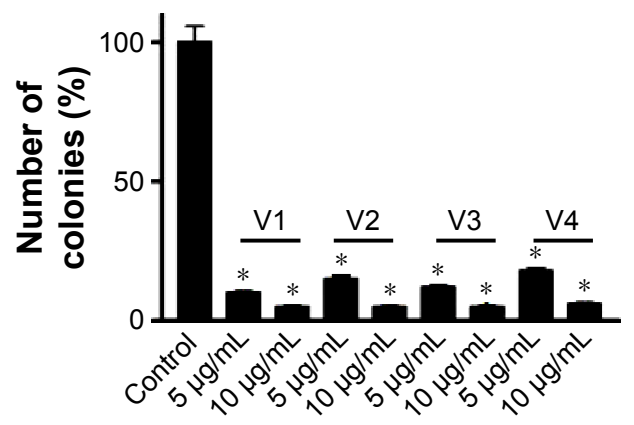

B
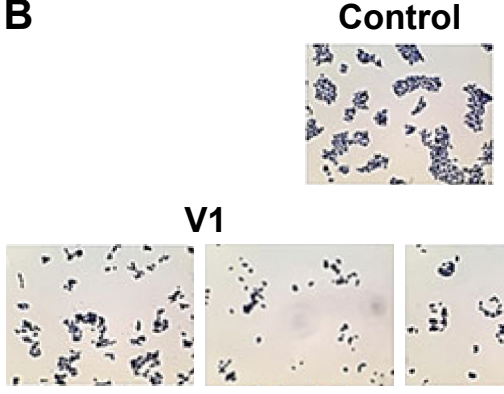

$5 \mu \mathrm{g} / \mathrm{mL}$

$10 \mu \mathrm{g} / \mathrm{mL}$

V3

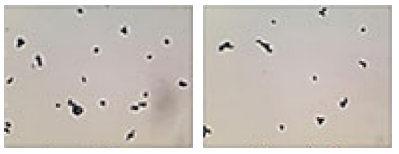

$5 \mu \mathrm{g} / \mathrm{mL}$

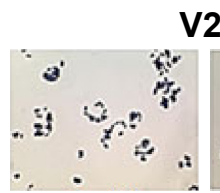

$5 \mu \mathrm{g} / \mathrm{mL}$

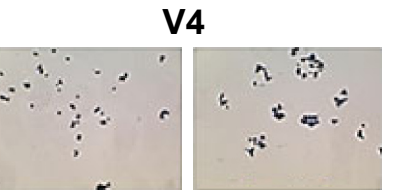

$5 \mu \mathrm{g} / \mathrm{mL}$
2

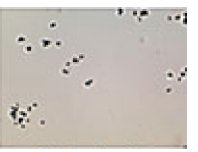

$10 \mu \mathrm{g} / \mathrm{mL}$

$10 \mu \mathrm{g} / \mathrm{mL}$

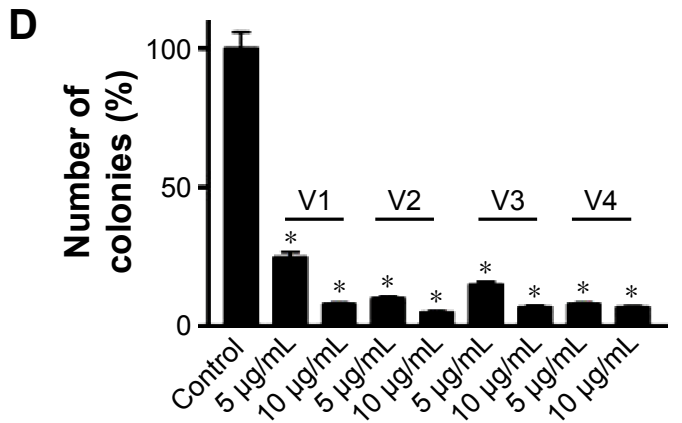

Figure I Clonogenic assay.

Notes: Anchorage-dependent colony formation assay shows a significant reduction in colony formation in (A) HCT-8 and (B) MDA-MB-23I cell lines when treated with different concentrations of snake venoms. Quantitative analyses are given in the form of bar graphs for HCT-8 (C) and MDA-MB-23I (D). A significant decrease in the colony formation is evident. "V" followed by numbers represents the specific venom, VI, V2, V3, and V4 are the venoms obtained from the species of the snakes, namely Bitis arietans, Cerastes gasperettii, Echis coloratus, and Echis pyramidum, respectively. *Statistically significant values $(P<0.05)$. 

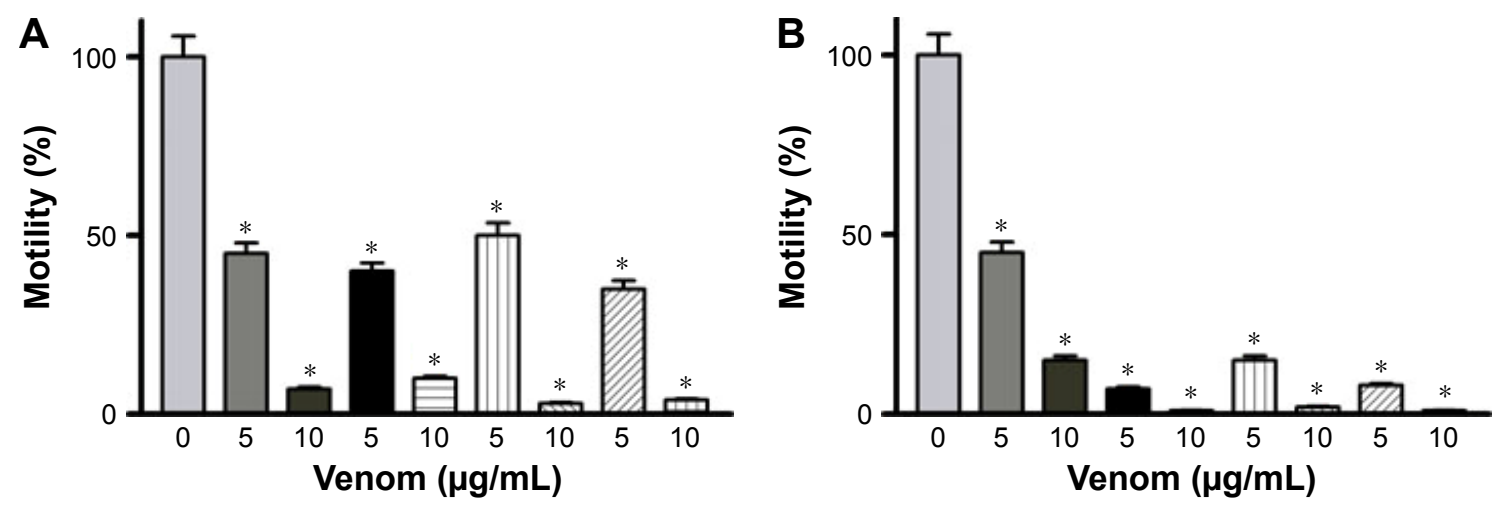

Figure 2 Scratch assay profile (A) HCT-8 and (B) MDA-MB-23I cell lines.

Notes: A dramatic decrease in cell motility was observed upon treatment with venom. Columns of the bar graphs show $80 \%-95 \%$ decrease in cell motility. $*$ Statistically significant $(P<0.05)$.

ROS blockers will be taken into account. These assays are currently beyond the scope of this article.

\section{Snake venoms cause late apoptosis in HCT-8 and MDA-MB-23I cancer cell lines}

To evaluate the extent of apoptosis in snake-venom-treated colorectal and breast cancer cell lines, an apoptosis assay

A

Control

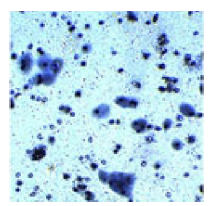

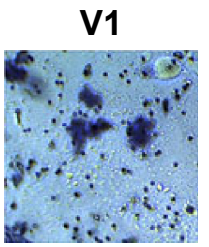

V2

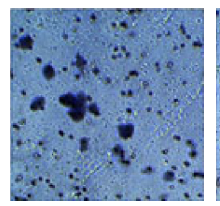

V3
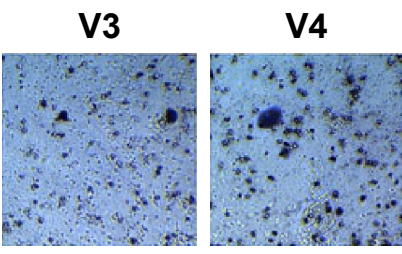

C

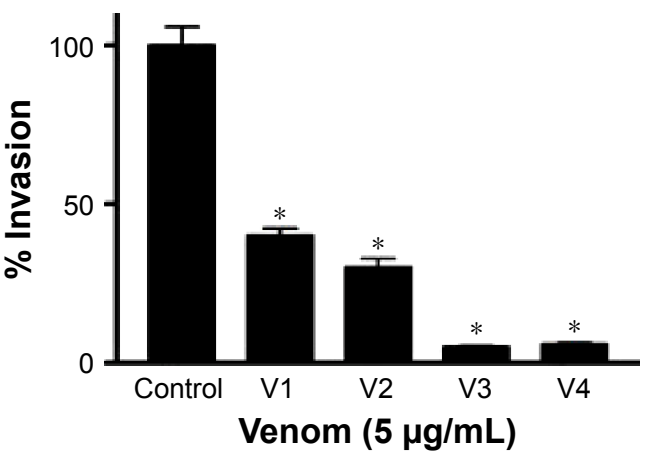

was performed using the Muse Cell Analyzer and Annexin V staining method. The number of apoptotic cells was high in venom-treated cell lines when compared with the control group (Figure $5 \mathrm{~A}$ and B). Approximately $60 \%-70 \%$ increase in total apoptotic cells was observed in HCT- 8 and MDAMB-231 cell lines. The quantitative analyses of these findings are also depicted in the form of bar graphs. The limitation of this study and the fact that the antibodies needed are not easily

B
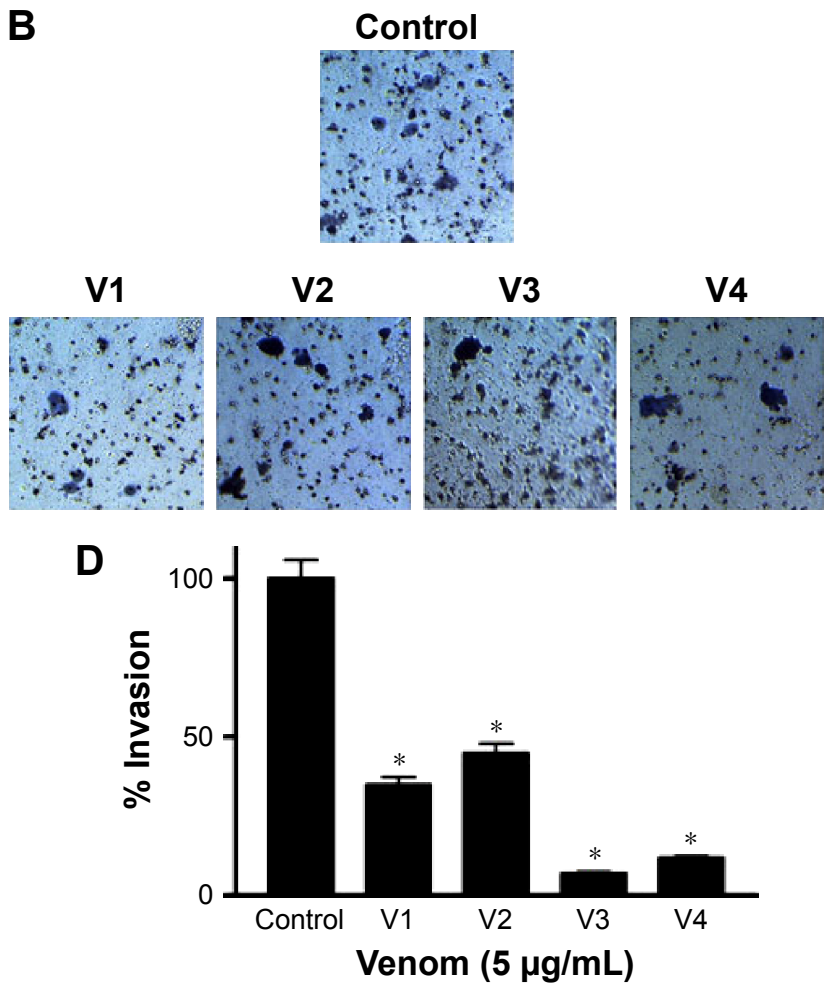

Figure 3 Matrigel cell invasion assay.

Notes: Cell invasion assay of (A) HCT-8 and (B) MDA-MB-23I cell lines treated with snake venoms. Bar graphs (C and $\mathbf{D})$ show the quantitative analyses of the invasion of HCT-8 and MDA-MB-23I cell lines, respectively. *Statistically significant $(P<0.05)$. VI, V2, V3, and V4 are the venoms obtained from the species of the snakes, namely Bitis arietans, Cerastes gasperettii, Echis coloratus, and Echis pyramidum, respectively. 
available to evaluate the status of caspases (caspase-3 and/or caspase-9) in venom-treated cell lines. However, this important point will be incorporated in our subsequent studies.

\section{Expression of IL-6 and IL-8 is}

\section{downregulated in venom-treated HCT-8} and MDA-MB-23 I cancer cell lines

Elevated ILs such as IL-6, IL-8, and VEGF are proven markers of cancer progression. ${ }^{21,25}$ Keeping in view the proactive role of these cytokines in malignancy, we evaluated the expression of IL-8 and IL-6 in HCT-8 and MDA-MB-231 cancer cell lines after treating them with snake venoms. As shown in Figure 6A and B, a dramatic decrease in IL-8 and
IL-6 expressions was observed in the HCT-8 cancer cell line upon treatment with venoms. Similar downtrend in the expression of these cytokines was also observed in the MDA-MB-231 cell line (Figure 6C and D).

\section{Expression of RhoC and $p-E_{k}{ }^{1 / 2}$ is downregulated in the MDA-MB-23 I cancer cell line}

To dissect the possible signaling mechanism that might be disrupted in the venom-treated cell line, we checked the expression level of RhoC, which is a metastatic protein and constitutively active in many cancer types. ${ }^{20,26}$ In addition, we looked at the phosphorylation state of $\mathrm{Erk}^{1 / 2}$, a downstream

A

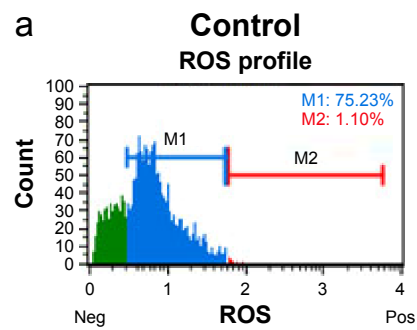

b

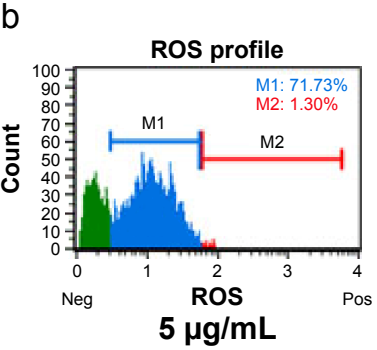

d

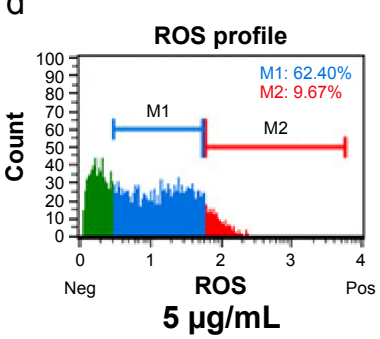

V1

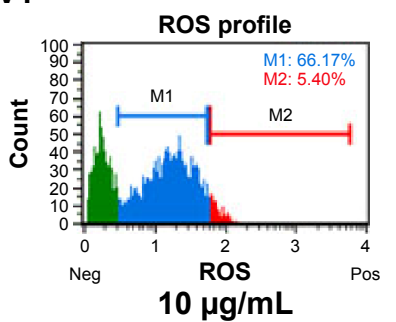

V3

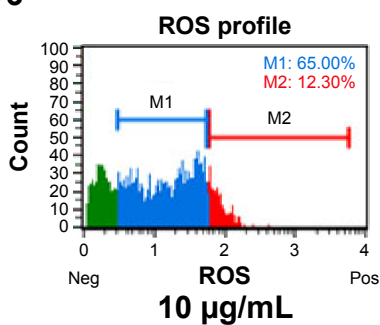

C

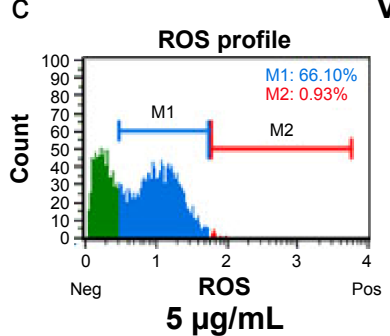

e

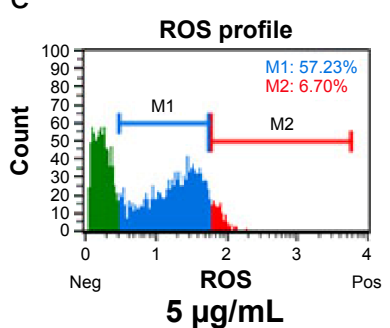

V2

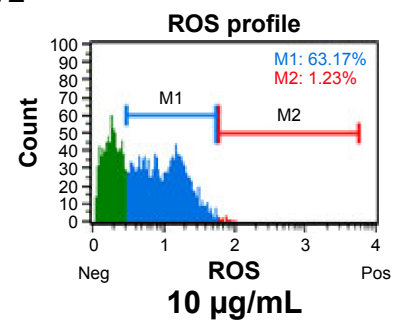

V4

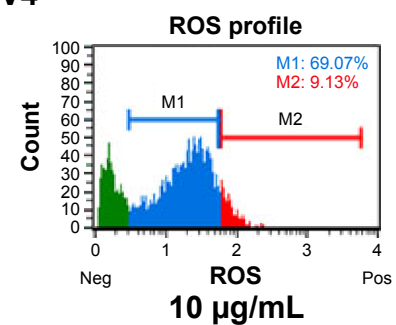

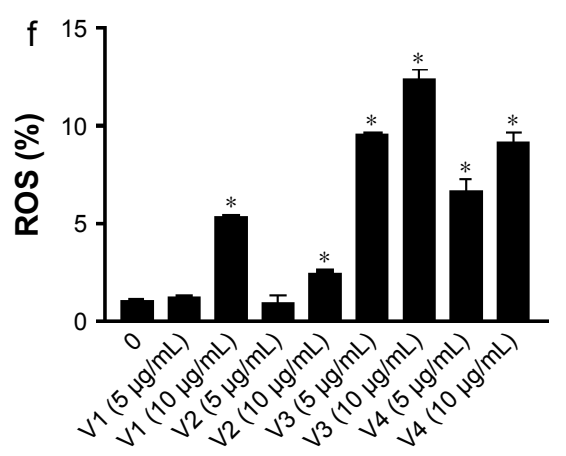

Figure 4 (Continued) 

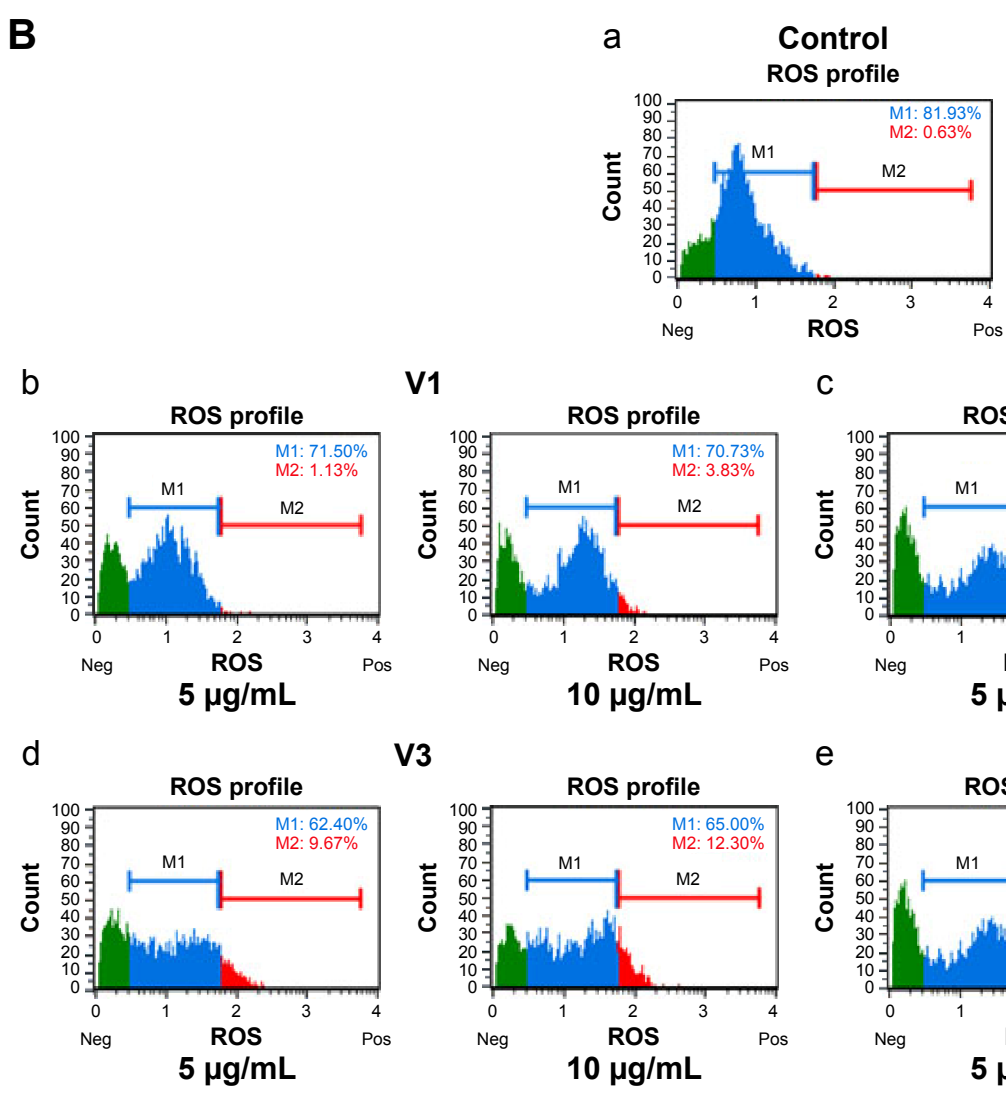

C

V3

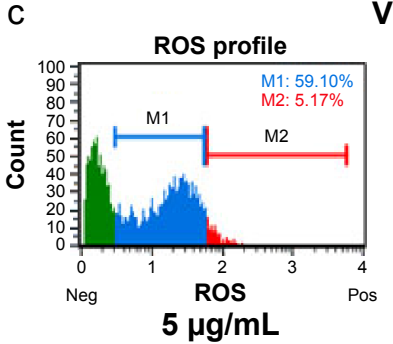

V2

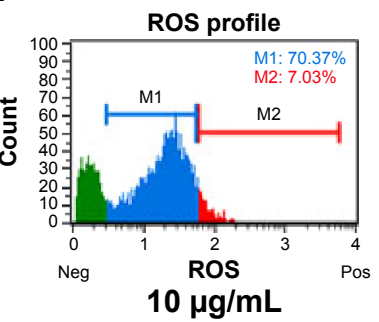

e

V4
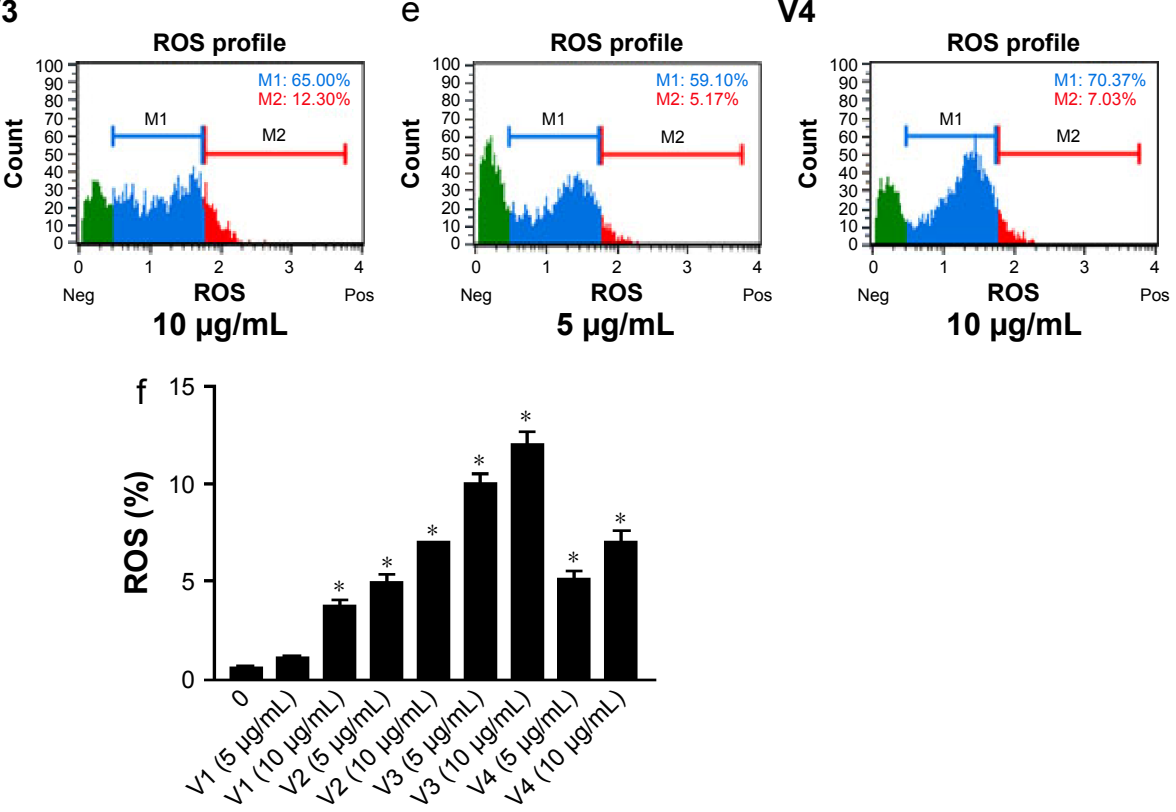

Figure 4 ROS was evaluated in (A) HCT-8 and (B) MDA-MB-23I cell lines, when treated with snake venoms for 24 hours.

Notes: Quantitative analyses of the ROS (+) were shown in the form of bar graphs (f), a=control, b=vl; $5 \mu \mathrm{g} / \mathrm{ml}$ and $10 \mu \mathrm{g} / \mathrm{ml}, \mathrm{c}=\mathrm{v} 2 ; 5 \mu \mathrm{g} / \mathrm{ml}$ and I0 $\mu \mathrm{g} / \mathrm{ml}, \mathrm{d}=\mathrm{v} 3 ; 5 \mu \mathrm{g} / \mathrm{ml}$ and $10 \mu \mathrm{g} / \mathrm{ml}, \mathrm{e}=\mathrm{v} 4 ; 5 \mu \mathrm{g} / \mathrm{ml}$ and I $0 \mu \mathrm{g} / \mathrm{ml}$. *P-values $\leq 0.05$ were considered significant. VI, V2, V3, and V4 are the venoms obtained from the species of the snakes, namely Bitis arietans, Cerastes gasperettii, Echis coloratus, and Echis pyramidum, respectively.

Abbreviations: Neg, negative; Pos, positive; ROS, reactive oxygen species.

target of RhoC. ${ }^{26}$ Interestingly, we found a decrease in the expression of RhoC in venom-treated MDA-MB-231 cell line and a corresponding decrease in the phosphorylation of Erk $^{1 / 2}$ (Figure 7). It is worth mentioning in this study that one of the coauthors (MI) of this article previously showed the doublets of $\mathrm{p}^{44}$ and $\mathrm{p}^{42}$ distinctly when using the primary antibody from cell signaling. ${ }^{19,26}$ However, this newly antibody procured from Abcam failed to show doublets, and instead a single band appeared in the Western blot; this could be attributed toward the selective specificity of this particular batch of the primary antibody.

\section{Discussion}

Approximately $15 \%$ of the total snakes found worldwide possess lethal venoms that are potentially dangerous for human life. ${ }^{27}$ Snake venoms are composed of a complex mixture of proteins and peptides, which constitute $\sim 95 \%$ of its dry weight. ${ }^{27}$ In addition, some snake venoms also contain carbohydrate, lipids, amines, and free amino acids. ${ }^{28}$ The distressing effect of snake venom is due to the catalytic activity of the enzyme present in it. The venoms are also known to contain proteolytic and hydrolytic enzymes, proteases, proteinases, and endopeptidases. ${ }^{29}$ However, the beneficial qualities of 
A

b

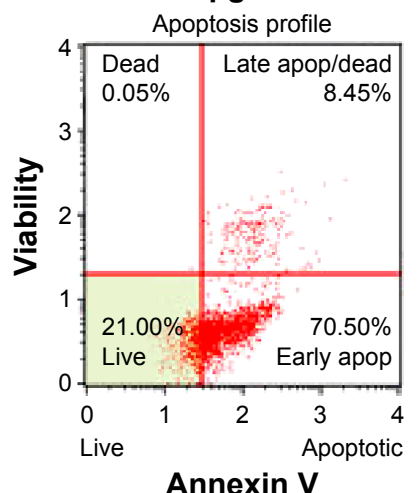

d

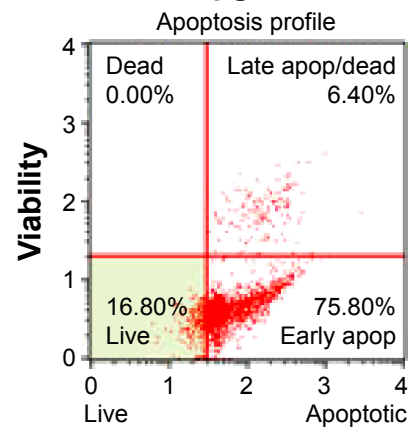

Annexin V

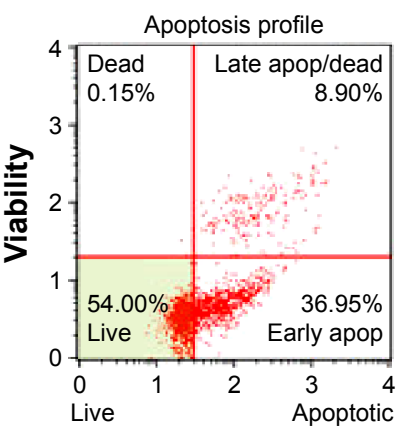

Annexin V

V1

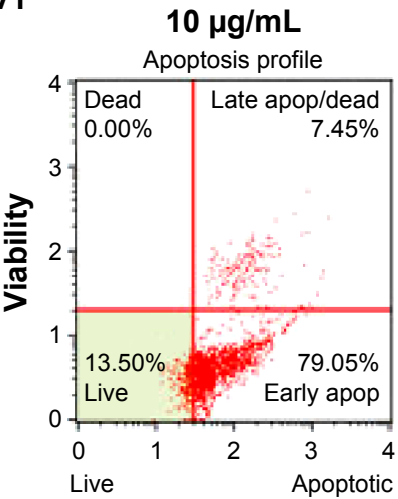

Annexin V

V3

$10 \mu \mathrm{g} / \mathrm{mL}$

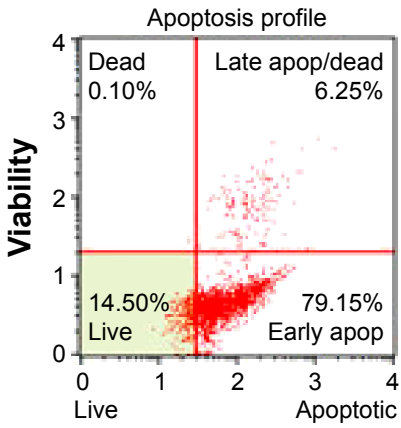

Annexin V
C

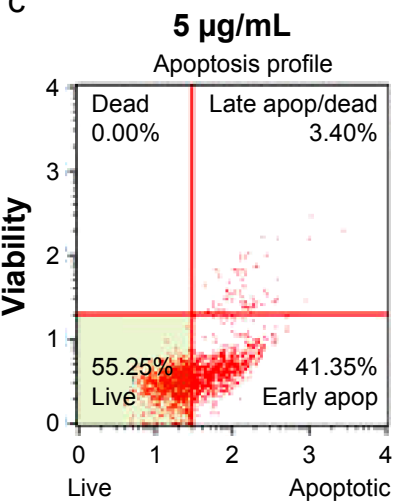

Annexin V

e

$5 \mu \mathrm{g} / \mathrm{mL}$

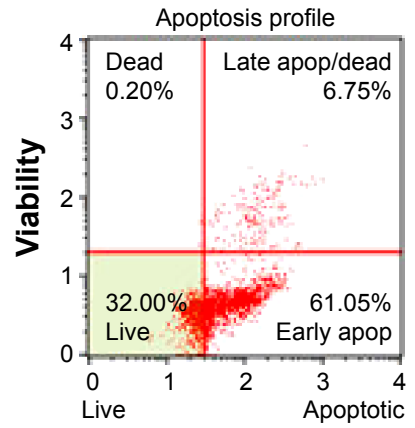

Annexin V
V2

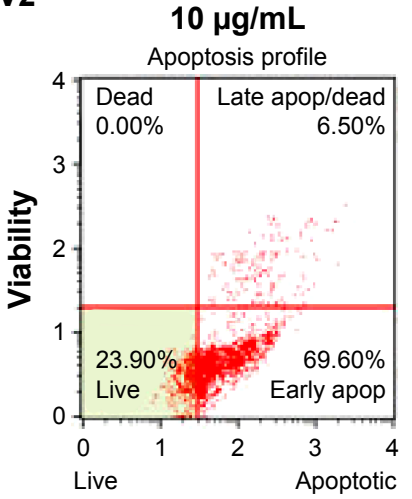

Annexin V

V4

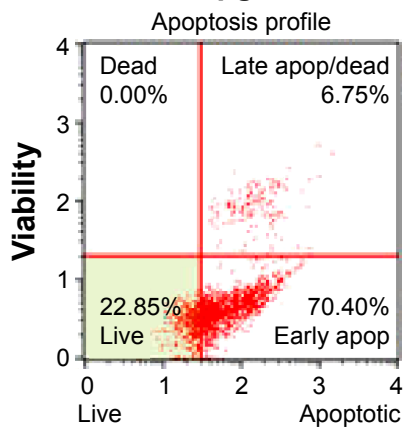

Annexin V

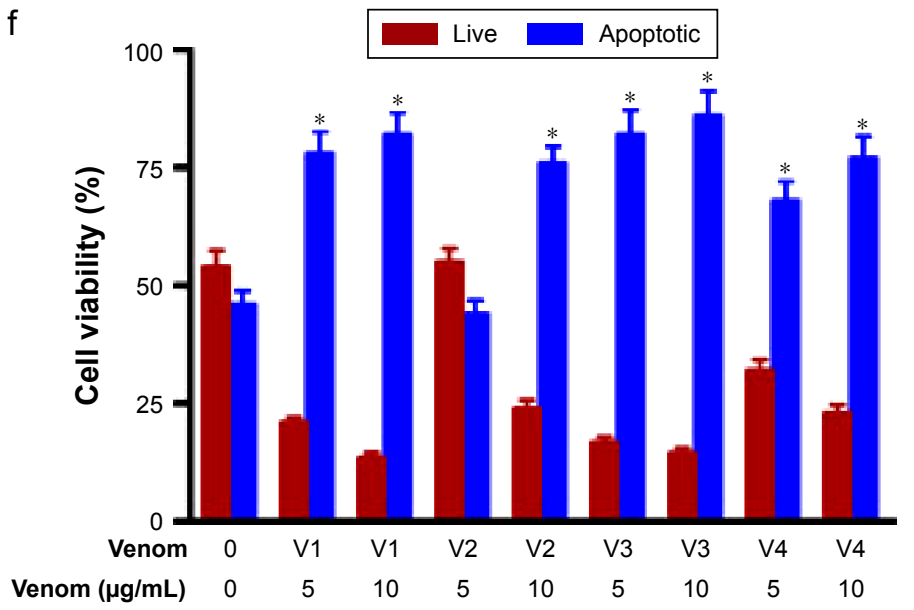

Figure 5 (Continued) 
B

b

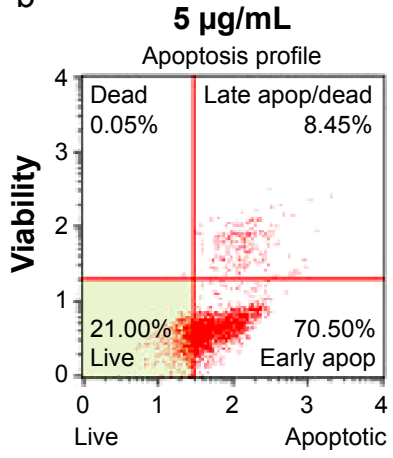

Annexin V

d

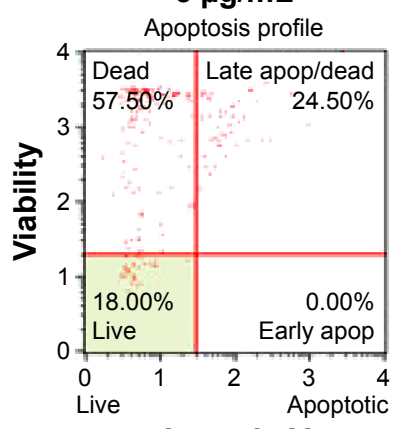

Annexin V a

Control

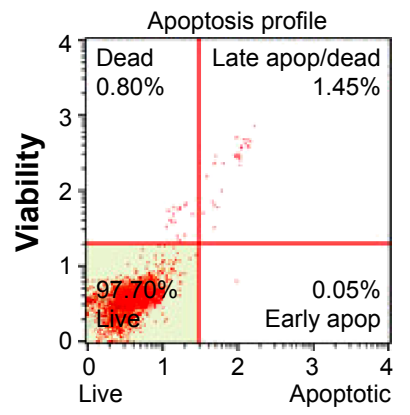

Annexin V

V1

$10 \mu \mathrm{g} / \mathrm{mL}$

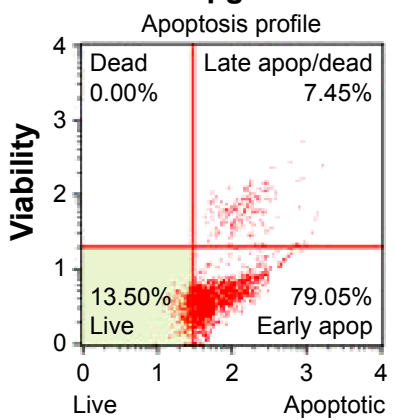

Annexin V

V3

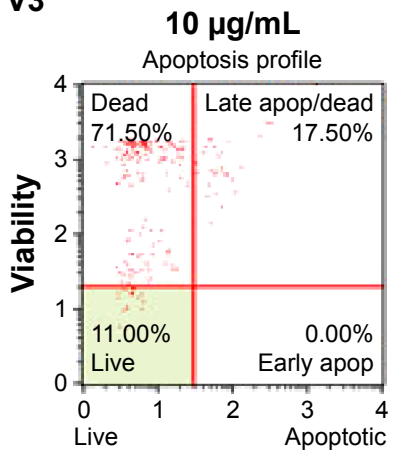

C

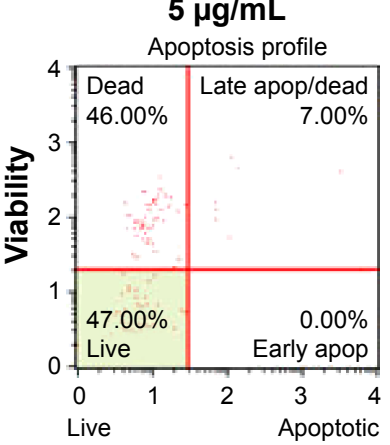

Annexin V

e

$5 \mu \mathrm{g} / \mathrm{mL}$

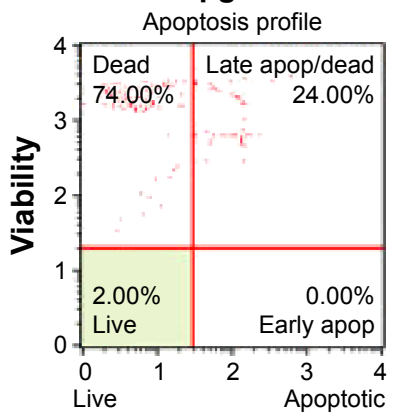

Annexin V
V2

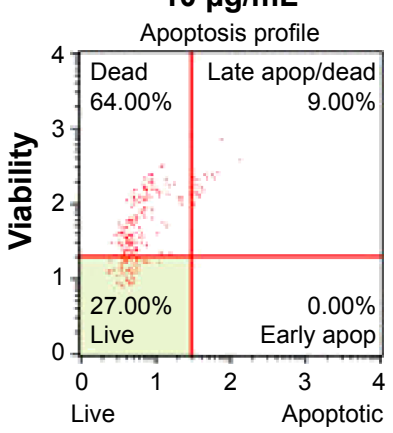

Annexin V

V4

$10 \mu \mathrm{g} / \mathrm{mL}$

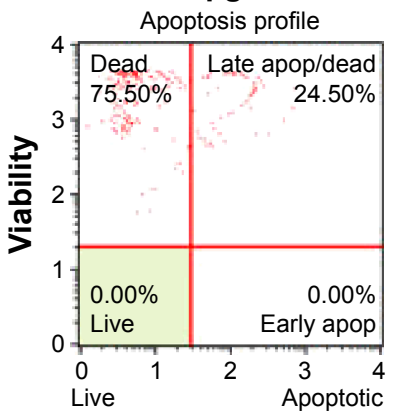

Annexin V

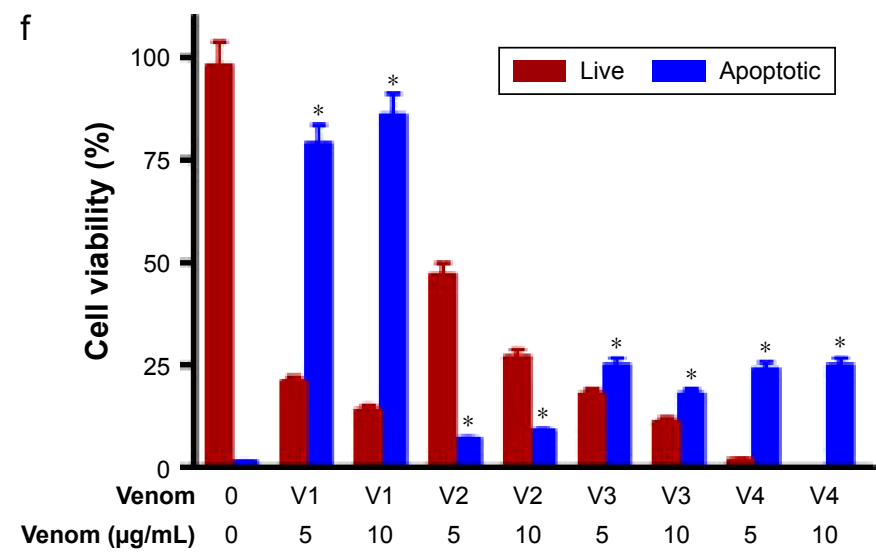

Figure 5 Assessment of apoptosis in (A) HCT-8 and (B) MDA-MB-23I cell lines treated with different snake venoms for 24 hours.

Notes: The cells cultured in either DMEM or RPMI medium in the absence of venoms were used as control. Extent of apoptosis was detected by Annexin V-PI dual staining. The percentage of total apoptotic cells (early + late) was calculated and shown in the bar graphs (f), a=control, b= vl; $5 \mu \mathrm{g} / \mathrm{ml}$ and I0 $\mu \mathrm{g} / \mathrm{ml} \mathrm{c}=\mathrm{v} 2 ; 5 \mu \mathrm{g} / \mathrm{ml}$ and $\mathrm{I} 0 \mu \mathrm{g} / \mathrm{ml}, \mathrm{d}=$ v3; $5 \mu \mathrm{g} / \mathrm{ml}$ and $10 \mu \mathrm{g} / \mathrm{ml}$, e= v4; $5 \mu \mathrm{g} / \mathrm{ml}$ and $10 \mu \mathrm{g} / \mathrm{ml}$. The number of apoptotic cells was higher in the venom-treated cell lines when compared with the control group. *Statistically significant $(P<0.05)$. VI, V2, V3, and V4 are the venoms obtained from the species of the snakes, namely Bitis arietans, Cerastes gasperettii, Echis coloratus, and Echis pyramidum, respectively.

Abbreviations: DMEM, Dulbecco's Modified Eagle's Medium; PI, propidium iodine; RPMI, Roswell Park Memorial Institute. 
A

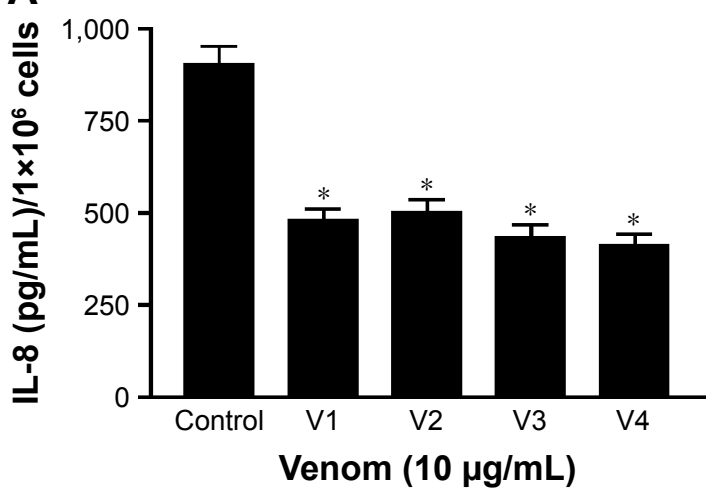

B

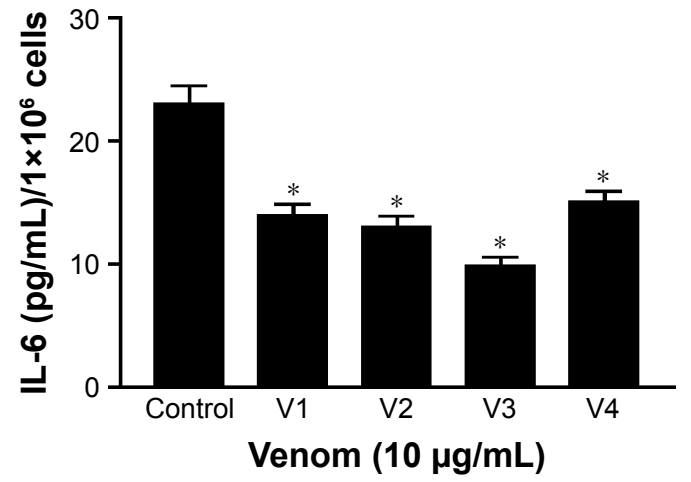

C

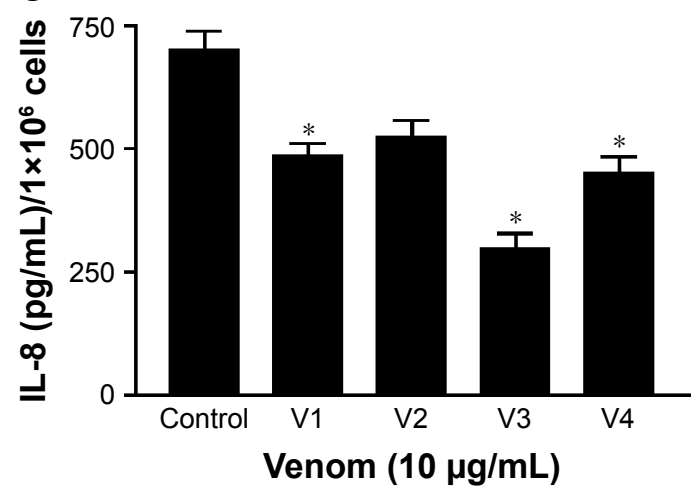

D

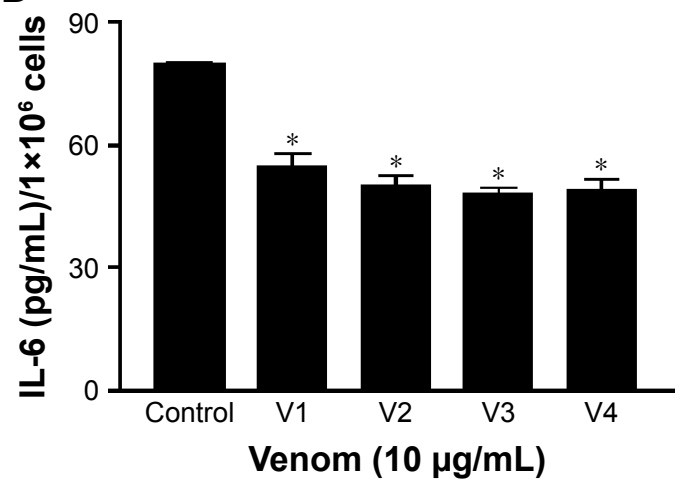

Figure 6 Expression of IL-8 and IL-6 determined by ELISA.

Notes: (A and B) The expression of IL-8 and IL-6 in HCT-8 cell line. (C and D) The expression of IL-8 and IL-6 in MDA-MB-23I cell line. *Statistically significant (P $\leq 0.05)$. $\mathrm{VI}, \mathrm{V} 2, \mathrm{~V} 3$, and V4 are the venoms obtained from the species of the snakes, namely Bitis arietans, Cerastes gasperettii, Echis coloratus, and Echis pyramidum, respectively. Abbreviations: ELISA, enzyme-linked immunosorbent assay; IL, interleukin.

A

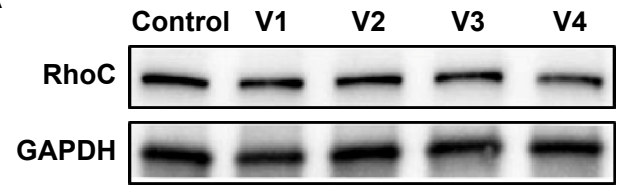

B

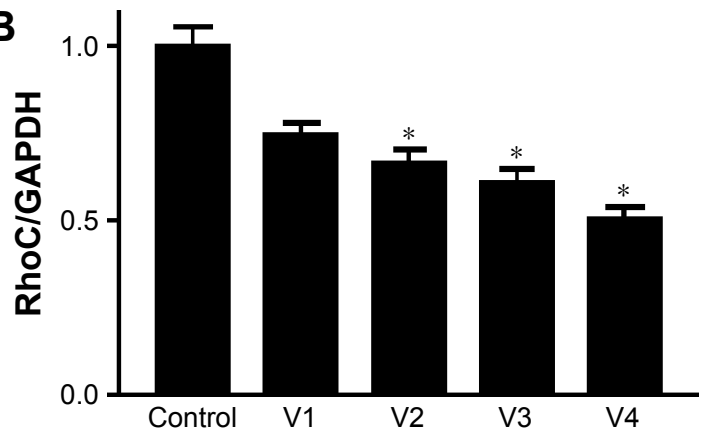

C

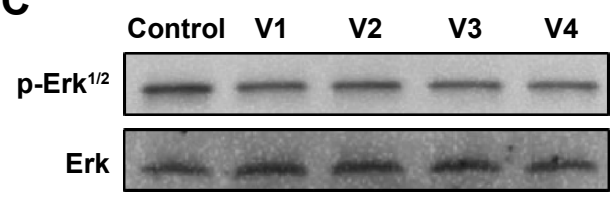

D

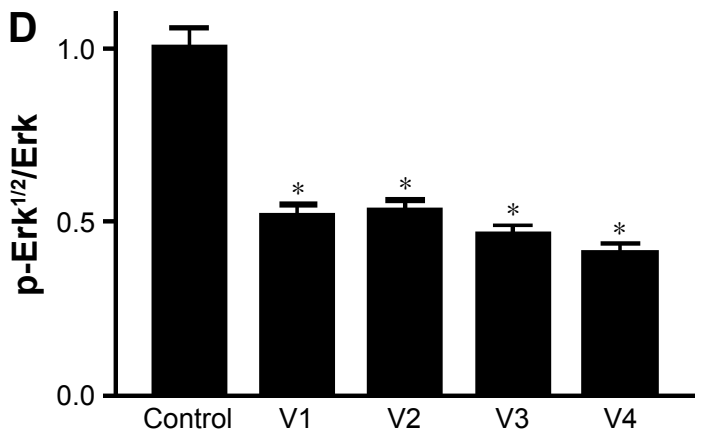

Figure 7 Western blot analyses performed on W3 Western Workflow.

Notes: Equal amounts of proteins from venom-treated and control cell lines were separated on $10 \%-12 \%$ gradient gels. Membranes were probed with $\mathrm{p}$-Erk ${ }^{1 / 2}$, RhoC, and GAPDH primary antibodies $(I: I, 000)$ and anti-rabbit IgG-HRP-conjugated secondary antibody $(I: 2,500)$. Protein bands were visualized in ChemiDoc MP imaging system after treating the membranes with ECL for 5 minutes at room temperature in dark. Densitometric analyses were performed using Image-J programing. VI, V2, V3, and V4 are the venoms obtained from the species of the snakes, namely Bitis arietans, Cerastes gasperettii, Echis coloratus, and Echis pyramidum, respectively. $\mathbf{A}=\mathrm{Western}$ blot of RhoC, $\mathbf{B}=$ Normalized band density of RhoC by GAPDH, $\mathbf{C}=$ Western blot of P-Erk ${ }^{1 / 2}, \mathbf{D}=$ Normalized band density of $\mathrm{p}$-Erk I/2 by total Erk. *Statistically significant. Abbreviation: $\mathrm{ECL}$, enhanced chemiluminescence. 
snake venoms are also well recognized, especially in the therapy of chronic diseases. ${ }^{12}$ Among these chronic diseases is cancer, which is treated by conventional chemotherapy and radiation therapy. In spite of tremendous advancement in the modes of treatment of cancer, the rate of survival in many cancer types has not significantly improved. Therefore, treatment using snake venoms could open a new era in the field of health sciences for various chronic immunological disorders as well as cancer in the future. ${ }^{30}$

Keeping in view the importance of snake venoms, we have investigated its effect on two cancer cell lines, namely HCT-8 (colorectal) and MDA-MB-231 (breast). Our first and foremost aim was to investigate the changes in the phenotypic appearances of these cell lines upon treatment with venoms. Various anticancer proteins and peptides are present in snake venoms, which are responsible for impeding the growth and development of cancer cells. ${ }^{31}$ Cell motility, anchoragedependent colony formation, and cell invasion are the very basic but immensely important parameters that allow assessment of the growth and survival of cancer. In our study, we have shown a remarkable decrease in these three parameters after treating the colorectal and breast cancer cell lines with snake venoms (Figures 1-3).

It is worth noting that integrin, a surface adhesion protein, is highly expressed in malignancy and promotes cancer metastasis. ${ }^{32,33}$ Furthermore, Liu et $\mathrm{al}^{4}$ and Calderon et $\mathrm{al}^{34}$ reported many anticancer bioactive molecules present in the snake venoms. In our study, we also observed cell disintegrity that was clearly observable due to severe distortion in colony formation and cell movement in the snake-venom-treated cell lines. Our results are also in accordance with their findings. Therefore, it can be postulated that the disruption of normal cellular architecture in the presence of snake venoms is probably due to the loss of the functional integrin. Furthermore, Ahn et $\mathrm{al}^{35}$ have purified and characterized snake venoms and reported the predominant presence of L-amino acid oxidase in it. In addition to this, they observed the cytotoxic effect of this enzyme on various cancer types such as fibrosarcoma, colorectal carcinoma, and gastric cancer.

Next, in this study, we found a significant enhancement in ROS in colorectal and breast cancer cell lines when treated with snake venoms (Figure 4A and B). The effect was more pronounced and universal when we used $10 \mu \mathrm{g} / \mathrm{mL}$ of venom concentration, especially for V1 and V2. This elevated expression of ROS could be attributed toward the presence of L-amino acid oxidase in snake venoms which contributes to the generation of free ROS. We have demonstrated an increase in the number of apoptotic cells upon treatment with snake venoms. The increase in total apoptotic cells was as high as $70 \%$ when compared with their corresponding controls (Figure 5A and B). In addition, ROS is known to damage DNA and alter drug sensitivity in cancer. ${ }^{36,37}$ While cells are under stress due the presence of snake venoms, the phenomenon of DNA damage is amplified multifold. In the same line of research, Aitken et $\mathrm{al}^{38}$ reported the generation of free oxygen species which leads to the state of oxidative stress by L-amino acid oxidase in equine spermatozoa. In addition, Park et $\mathrm{al}^{39}$ demonstrated that in neuroblastoma cells an increase in ROS due to treatment with snake venoms increases pro-apoptotic proteins including Bax, and there was a downregulation of anti-apoptotic Bcl-2 protein upon treatment with venom. Our study is in good agreement with these published reports. Park et al ${ }^{12}$ also showed that the elevated ROS increases the apoptosis in colon cancer cell line. Therefore, we can correlate our findings based on the previously published work that an increase in the rate of apoptosis in colorectal and breast cancer cell lines is the manifestation of overproduction of ROS when the cells are challenged with snake venoms. In this study, we observed that the low concentration of $\mathrm{V} 1$ could not produce a significant amount of ROS but showed a significant number of apoptotic cells upon treatment; this discrepancy could be attributed toward the differential cellular uptake of the venom by the cell line in this particular setup of the experiment.

In addition, when the cell lines were treated with venoms, we observed a decrease in the expression of IL- 8 in HCT-8 and MDA-MB-231 cell lines (Figure 6A and C), which can be correlated with the increase in the number of apoptotic cells. Choi et $\mathrm{al}^{40}$ also reported a similar phenomenon in hepatocellular carcinoma, where knocking down of IL-8 and HIF- $1 \alpha$ increases the concentration of cytochrome $\mathrm{C}$ and consequently increases DNA fragmentation and apoptosis. We also observed a decrease in the expression of IL-6 upon treatment with venom in both cell lines, which is also directly proportional to the increase in the level of apoptosis (Figure 6B and C). The ROS and certain pro-inflammatory cytokines are constitutively elevated during malignancy. It has also been reported that IL-6 protects gastric cancer cells undergoing apoptosis, induced by hydrogen peroxide. ${ }^{41}$ Our findings are also in agreement with this report, as reduced expression of IL-6 in venom-treated cell lines positively correlates with the increased number of apoptotic cells.

To elucidate the molecular mechanism of signaling cascade in snake-venom-treated cell lines, we examined 


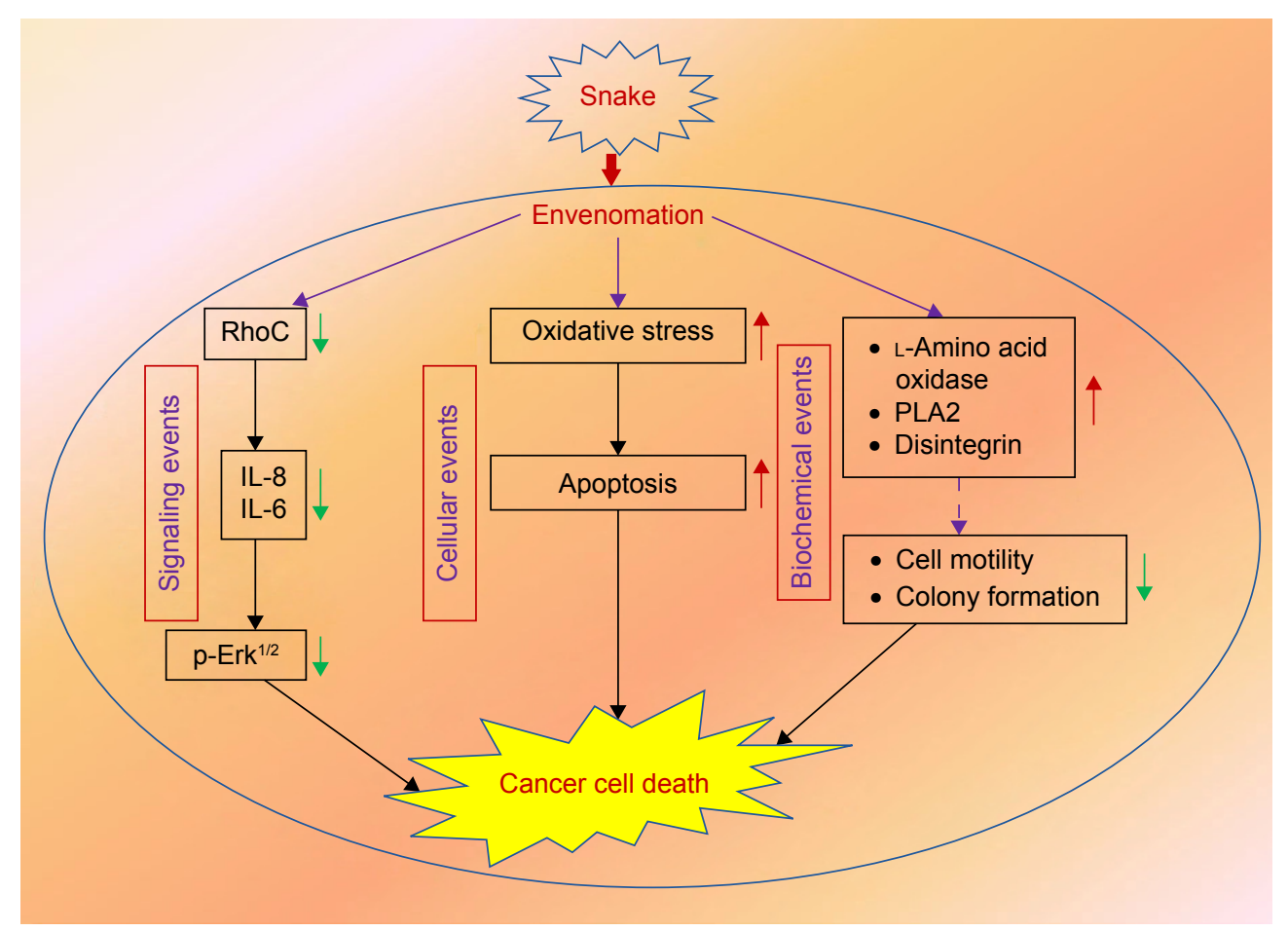

Figure 8 Schema showing the probable mechanism of action of the venom against cancer.

Abbreviations: IL, interleukin; PLA2, phospholipase A2.

the expression of RhoC, which is a pro-metastatic oncoprotein, constitutively active in many cancer types including head and neck squamous cell carcinoma. ${ }^{20}$ Interestingly, a decrease in the expression of RhoC in the MDA-MB-231 cell line directly correlates with a decrease in metastatic aggressiveness of the breast cancer cell line upon treatment with venom. ${ }^{42}$ The role of Erk ${ }^{1 / 2}$ in cancer metastasis is well established..$^{10}$ In this study, we found a significant downregulation of $\mathrm{p}$-Erk ${ }^{1 / 2}$ upon treatment with venom. Our results are in accordance with the involvement of MAP kinase in cancer progression. ${ }^{20}$ The exact mechanism of the action of snake venom in signal transduction has not yet been characterized. However, we can postulate that RhoC may be an intermediate molecule through which directly or indirectly the activation of Erk ${ }^{1 / 2}$ takes place (Figure 7). A schema of the probable mechanism of the action of snake venoms against cancer is shown in Figure 8. The concept of the schema is based on the findings depicted in Figures 6 and 7. When RhoC was downregulated, a decrease in the expression of IL-6/IL-8 was observed in the venom-treated cell line. Therefore, it can be postulated that a decrease in the activation of $\mathrm{Erk}^{1 / 2}$ is the manifestation of the downregulation of RhoC and IL-6. Furthermore, a study conducted by Islam et $\mathrm{al}^{10}$ showed that the effect of downregulation of RhoC results in a corresponding downregulation of IL-6 in head and neck squamous cell carcinoma.
An implication of this study is that it may very likely allow for the development of snake-venom-based anticancer drugs that are less costly compared with current ones. This is due to the abundance of snake venoms and the relative ease of their isolation and purification of the active anticancer components; it will be more feasible and conducive for patients suffering from cancer to avail of these alternate treatment strategies. In summary, venom therapy may allow for the development of a new era in the treatment of various chronic immunological illnesses in general and in cancer therapy in particular. ${ }^{12,43,44}$

\section{Conclusion}

The findings presented in this study demonstrate that reduced cell motility, cell invasion potential, colony formation, high apoptosis, and elevated ROS, along with the lowering of the pro-inflammatory cytokines, coupled with the downregulation of $\mathrm{RhoC}$ and $\mathrm{p}-\mathrm{Erk}^{1 / 2}$, correlate strongly with the inhibitory role of snake venoms on colorectal and breast cancer cell lines. Furthermore, these finding suggests that venom therapy will be an important step toward a more specific treatment for aggressive forms of cancer.

\section{Acknowledgments}

The authors thank the PSMMC hospital and its Research Center for providing all the necessary facilities to conduct 
this study, and they also thank Doctor James C Lang, The Ohio State University, Columbus, $\mathrm{OH}$, USA, for the critical reading of this manuscript.

\section{Disclosure}

The authors report no conflicts of interest in this work.

\section{References}

1. Kasturiratne A, Wickremasinghe AR, de Silva N, et al. The global burden of snakebite: a literature analysis and modelling based on regional estimates of envenoming and deaths. PLoS Med. 2008;5(11):e218.

2. Al-Sadoon MK. Survey of the reptilian fauna of the Kingdom of Saudi Arabia: the snake fauna of the Central Region. J King Saud Univ. 1989; 1(2):53-61.

3. Soares AM, Giglio JR. Chemical modifications of phospholipases A 2 from snake venoms: effects on catalytic and pharmacological properties. Toxicon. 2003;42(8):855-868.

4. Liu C-C, Yang H, Zhang L-L, Zhang Q, Chen B, Wang Y. Biotoxins for cancer therapy. Asian Pac J Cancer Prev. 2013;15(12):4753-4758.

5. Marsh N, Williams V. Practical applications of snake venom toxins in haemostasis. Toxicon. 2005;45(8):1171-1181.

6. Finn R. Snake venom protein paralyzes cancer cells. J Natl Cancer Inst. 2001;93(4):261-262.

7. Shanbhag VKL. Applications of snake venoms in treatment of cancer. Asian Pac J Trop Biomed. 2015;5(4):275-276.

8. Vyas VK, Brahmbhatt K, Bhatt H, Parmar U. Therapeutic potential of snake venom in cancer therapy: current perspectives. Asian Pac J Trop Biomed. 2013;3(2):156-162.

9. Yamazaki Y, Morita T. Snake venom components affecting blood coagulation and the vascular system: structural similarities and marked diversity. Curr Pharm Des. 2007;13(28):2872-2886.

10. Islam M, Sharma $S, T e k n o s ~ T N$. RhoC regulates cancer stem cells in head and neck squamous cell carcinoma by overexpressing IL-6 and phosphorylation of STAT3. PLoS One. 2014;9(2):e88527.

11. Pan G, Thomson JA. Nanog and transcriptional networks in embryonic stem cell pluripotency. Cell Res. 2007;17(1):42-49.

12. Park MH, Jo M, Won D, et al. Snake venom toxin from Vipera lebetina turanica induces apoptosis of colon cancer cells via upregulation of ROS and JNK-mediated death receptor expression. BMC Cancer. 2012;12(1):228.

13. Gasperetti J. Snakes of Arabia. Fauna Saudi Arabia. 1988;9(169):450.

14. Al-Asmari A, Osman NA, Aziz A, Aman AM, Khan MW. Studies on effect of viper venom on serum electrolytes and trace element levels in rats. J Biol Sci. 2013;1(2):8-14.

15. Vermeulen SJ, Chen TR, Speleman F, Nollet F, Van Roy FM, Mareel MM. Did the four human cancer cell lines DLD-1, HCT-15, HCT-8, and HRT-18 originate from one and the same patient? Cancer Genet Cytogenet. 1998;107(1):76-79.

16. Cailleau R, Young R, Olive M, Reeves WJ Jr. Breast tumor cell lines from pleural effusions. J Natl Cancer Inst. 1974;53(3):661-674.

17. Al-Asmari AK, Albalawi SM, Athar MT, Khan AQ, Al-Shahrani H, Islam M. Moringa oleifera as an anti-cancer agent against breast and colorectal cancer cell lines. PLoS One. 2015;10(8):e0135814.

18. Datta J, Smith A, Lang JC, et al. microRNA-107 functions as a candidate tumor-suppressor gene in head and neck squamous cell carcinoma by downregulation of protein kinase C $\varepsilon$. Oncogene. 2012;31(36): 4045-4053.

19. Islam M, Sharma S, Kumar B, Teknos TN. Atorvastatin inhibits RhoC function and limits head and neck cancer metastasis. Oral Oncol. 2013; 49(8):778-786.

20. Islam M, Lin G, Brenner JC, et al. RhoC expression and head and neck cancer metastasis. Mol Cancer Res. 2009;7(11):1771-1780.

21. Duffy SA, Taylor JM, Terrell JE, et al. Interleukin-6 predicts recurrence and survival among head and neck cancer patients. Cancer. 2008; 113(4):750-757.
22. Laemmli UK. Cleavage of structural proteins during the assembly of the head of bacteriophage T4. Nature. 1970;227(5259):680-685.

23. Matés JM, Sánchez-Jiménez FM. Role of reactive oxygen species in apoptosis: implications for cancer therapy. Int J Biochem Cell Biol. 2000;32(2):157-170.

24. Ozben T. Oxidative stress and apoptosis: impact on cancer therapy. J Pharm Sci. 2007;96(9):2181-2196.

25. Marcus B, Arenberg D, Lee J, et al. Prognostic factors in oral cavity and oropharyngeal squamous cell carcinoma. Cancer. 2004;101(12): 2779-2787.

26. Islam M, Datta J, Lang JC, Teknos TN. Down regulation of RhoC by microRNA-138 results in de-activation of FAK, Src and Erk1/2 signaling pathway in head and neck squamous cell carcinoma. Oral Oncol. 2014;50(5):448-456.

27. Gold BS, Dart RC, Barish RA. Bites of venomous snakes. $N$ Engl $J$ Med. 2002;347(5):347-356.

28. de Vieira Santos MM, Sant'Ana CD, Giglio JR, et al. Antitumoural effect of an 1-amino acid oxidase isolated from Bothrops jararaca snake venom. Basic Clin Pharmacol Toxicol. 2008;102(6):533-542.

29. Kitchens CS, Eskin TA. Fatality in a case of envenomation by Crotalus adamanteus initially successfully treated with polyvalent ovine antivenom followed by recurrence of defibrinogenation syndrome. $J$ Med Toxicol. 2008;4(3):180-183.

30. Kalam Y, Isbister GK, Mirtschin P, Hodgson WC, Konstantakopoulos N. Validation of a cell-based assay to differentiate between the cytotoxic effects of elapid snake venoms. J Pharmacol Toxicol Methods. 2011;63(2):137-142.

31. Debatin KM, Krammer PH. Death receptors in chemotherapy and cancer. Oncogene. 2004;23(16):2950-2966.

32. Foubert $P$, Varner JA. Integrins in tumor angiogenesis and lymphangiogenesis. Methods Mol Biol. 2012;757:471-486.

33. Tchaicha JH, Reyes SB, Shin J, Hossain MG, Lang FF, McCarty JH. Glioblastoma angiogenesis and tumor cell invasiveness are differentially regulated by $\beta 8$ integrin. Cancer Res. 2011;71(20):6371-6381.

34. Calderon LA, Sobrinho JC, Zaqueo KD, et al. Antitumoral activity of snake venom proteins: new trends in cancer therapy. Biomed Res Int. 2014;2014:203639.

35. Ahn MY, Lee BM, Kim YS. Characterization and cytotoxicity of L-amino acid oxidase from the venom of king cobra (Ophiophagus hannah). Int J Biochem Cell Biol. 1997;29(6):911-919.

36. Pelicano H, Carney D, Huang P. ROS stress in cancer cells and therapeutic implications. Drug Resist Updat. 2004;7(2):97-110.

37. Schumacker PT. Reactive oxygen species in cancer cells: live by the sword, die by the sword. Cancer Cell. 2006;10(3):175-176.

38. Aitken JB, Naumovski N, Curry B, Grupen CG, Gibb Z, Aitken RJ. Characterization of an L-amino acid oxidase in equine spermatozoa. Biol Reprod. 2015;92(5):125.

39. Park MH, Son DJ, Kwak DH, et al. Snake venom toxin inhibits cell growth through induction of apoptosis in neuroblastoma cells. Arch Pharm Res. 2009;32(11):1545-1554.

40. Choi SH, Park JY, Kang W, et al. Knockdown of HIF-1alpha and IL-8 induced apoptosis of hepatocellular carcinoma triggers apoptosis of vascular endothelial cells. Apoptosis. 2016;21(1):85-95.

41. Lin MT, Juan CY, Chang KJ, Chen WJ, Kuo ML. IL-6 inhibits apoptosis and retains oxidative DNA lesions in human gastric cancer AGS cells through up-regulation of anti-apoptotic gene mcl-1. Carcinogenesis. 2001; 22(12):1947-1953.

42. van Golen KL, Wu Z-F, Qiao XT, Bao LW, Merajver SD. RhoC GTPase, a novel transforming oncogene for human mammary epithelial cells that partially recapitulates the inflammatory breast cancer phenotype. Cancer Res. 2000;60(20):5832-5838.

43. Jo M, Park MH, Kollipara PS, et al. Anti-cancer effect of bee venom toxin and melittin in ovarian cancer cells through induction of death receptors and inhibition of JAK2/STAT3 pathway. Toxicol Appl Pharmacol. 2012;258(1):72-81.

44. Park MH, Choi MS, Kwak DH, et al. Anti-cancer effect of bee venom in prostate cancer cells through activation of caspase pathway via inactivation of NF-אB. Prostate. 2011;71(8):801-812. 


\section{Publish your work in this journal}

OncoTargets and Therapy is an international, peer-reviewed, open access journal focusing on the pathological basis of all cancers, potential targets for therapy and treatment protocols employed to improve the management of cancer patients. The journal also focuses on the impact of management programs and new therapeutic agents and protocols on

patient perspectives such as quality of life, adherence and satisfaction. The manuscript management system is completely online and includes a very quick and fair peer-review system, which is all easy to use. Visit http://www.dovepress.com/testimonials.php to read real quotes from published authors.

Submit your manuscript here: http://www.dovepress.com/oncotargets-and-therapy-journal 